\title{
Quantity and Quality of Shallot (Allium ascalonicum L.) as Influenced by Water Hyacinth Compost on Fluventic Eutrudepts
}

\author{
Rizkyani Remona*, Emma Trinurani Sofyan, Benny Joy, Rija Sudirja, Anni Yuniarti, \\ Jajang Sauman Hamdani
}

Department of Soil Science, Faculty of Agriculture, Padjadjaran University, Bandung, Indonesia

Email address:

remonarizkyani@gmail.com (R. Remona),emma.trinurani@unpad.ac.id (E. T. Sofyan), bennyjoy52@yahoo.com (B. Joy)

${ }^{*}$ Corresponding author

To cite this article:

Rizkyani Remona, Emma Trinurani Sofyan, Benny Joy, Rija Sudirja, Anni Yuniarti, Jajang Sauman Hamdani. Quantity and Quality of Shallot (Allium ascalonicum L.) as Influenced by Water Hyacinth Compost on Fluventic Eutrudepts. American Journal of Biological and Environmental Statistics. Vol. 6, No. 3, 2020, pp. 50-57. doi: 10.11648/j.ajbes.20200603.13

Received: September 20, 2020; Accepted: October 5, 2020; Published: October 17, 2020

\begin{abstract}
One of the problems with Fluventic Eutrudepts is that it has a low level of soil fertility because the soil surface is effortless to wash. The solution to this problem is the addition of one or more available nutrients to optimize soil fertility so that it can increase quantity and quality plant. This experiment aims to find the best dosage of water hyacinth compost and N, P, $\mathrm{K}, \mathrm{S}$ fertilizer against changes in sulfur, quantity and quality of Batu Ijo Variety of shallots. This experiment was carried out at the Laboratory of Soil Chemistry and Plant Nutrition Experimental Garden, Faculty of Agriculture, Universitas Padjadjaran, Jatinangor, Sumedang from February to August 2020. The research approach used was a randomized block design (RBD) consisting of seven treatments and repeated four times, namely: control; N, P, K, S recommendations $(3 / 4,1)$; dosage of fertilizer N, P, K, S ( $(3 / 4,1)$; and the dosage of water hyacinth compost $\left(1 / 2,1,1 \frac{1}{2}\right)$. The results showed that the treatment dose of $25 \mathrm{t} / \mathrm{ha}$ of water hyacinth compost and $150 \mathrm{~kg} / \mathrm{ha}$ Urea, $225 \mathrm{~kg} / \mathrm{ha} \mathrm{SP}-36,150 \mathrm{~kg} / \mathrm{ha} \mathrm{KCl}, 375 \mathrm{~kg} / \mathrm{ha} \mathrm{ZA}$ was able to provide the best effect in increasing sulfur content, quantity, and the quality of shallots at Fluventic Eutrudepts.
\end{abstract}

Keywords: Compost, Shallot, Quality, Quantity, Water Hyacint

\section{Introduction}

Inceptisols from Jatinangor is included in the Udepts suborder, the Eutrudepts great group and the Fluventic Eutrudepts sub-group. Inceptisols are one of the land borders that are widespread in Indonesia, namely 70.52 million hectares (ha) or $37.5 \%$ of Indonesia's mainland area. Inceptisols have quite a prospective value for the cultivation of agricultural and plantation crops, particularly the development of food crops and horticulture [33]. Based on the results of the preliminary soil analysis on Inceptisols, the chemical properties are less fertile Several chemical properties which are indicators of soil fertility include slightly acidic $\mathrm{pH}$ content of $\mathrm{H}_{2} \mathrm{O}(6.48)$, low total $\mathrm{N}(0.19 \%)$, medium available $\mathrm{P}(10.72 \mathrm{mg} / \mathrm{kg})$ and medium K-potential $(31.54 \mathrm{mg} / 100 \mathrm{~g}), \mathrm{SO}_{4}{ }^{2-}$ very low $(5.11 \mathrm{mg} / \mathrm{kg})$, low Corganic $(1.83 \%)$, and medium Cation Exchange Capacity
(CEC) $(21.96 \mathrm{mmol} / \mathrm{kg})$. Based on this, it is necessary to add one or more available nutrients to optimize soil fertility so that it can increase quantity and quality plant.

The quantity and quality of plants can be improved by paying attention to soil fertility. Continuous application of inorganic fertilizers can result in decreased land productivity, one way to overcome the other impacts that will arise from the use of inorganic fertilizers is through compost. Compost is a product of decomposition of organic material derived from plants or animal waste as a result of an overhaul by microorganisms by producing simple and relatively stable organic matter. Water hyacinth is one source of organic material which is relatively abundant and so far not widely used. The nutrient content of water hyacinth compost is relatively high, namely $\mathrm{N}$ of $1.68 \%$, P of $3.69 \%$, K of $2.50 \%$, organic-C $31.92 \%, \mathrm{C} / \mathrm{N}$ ratio of 19 , and $\mathrm{S}$ of $900 . \mathrm{mg} / \mathrm{kg}$. The advantage of compost made from water hyacinth is that the 
elemental content of sulfur is higher than compost with a variety of raw materials [11, 27, 36].

Fertilization with N, P, K fertilizers balanced with organic fertilizers can improve the quality of tubers and tubers that are resistant to disease. In general, N, P, K fertilizers can stimulate the overall growth of both roots, stems and leaves; protein formation; and provide strength to leaves, contains and fruit, so they do not fall. In addition to N, P, K fertilizers, ZA fertilizer is necessary because it contains $24 \%$ sulfur and $21 \%$ nitrogen. Sulfur is a secondary macronutrient that can improve the quality of shallots. This nutrient is also essential for plants because it has a function for plant growth, compiling protein, and forming chlorophyll [8, 9, 41]. Lack of Sulfur will cause plants to grow stunted, thin, and new leaves will turn yellow.

Shallot farming is one type of vegetable farming that has good prospects to increase farmers' income and welfare. Shallots are included in seasonal crops, while the need for shallots continues to improve almost every day. The productivity of shallots in West Java Province in 2015 was $10.47 \mathrm{t} / \mathrm{ha}$ and decreased in 2016 , namely to $10.06 \mathrm{t} / \mathrm{ha}[24,6]$. The increase in the need for shallots must be balanced with an increase in the amount of production. According to data from the Ministry of Trade (2016) in 2005-2014, Indonesia was included in the ten countries with the largest average area of shallot harvest in the world. Still, Indonesia ranks 115 in the most massive average shallot productivity in the world.

Quality seeds are one of the influencing factors to increase the productivity of shallots, namely by using wide yielding varieties that are free of pests and pathogens and labelled. The use of high yield varieties is one approach that can be taken to spur increased productivity of shallots for both the highlands and the lowlands. There are quite a lot of released shallot varieties with high yield potential and wide adaptability, one of which is the Batu Ijo variety [30]. Batu Ijo is quite resistant to tuber blight but susceptible to late blight. This plant can be planted in the highlands and lowlands.

Sulfur is an essential part of protein and amino acids. Generally, organic S is the primary source of sulfur for plant growth. Soil organic matter is known as the primary contributor of available sulfur to plants. The decrease in soil organic matter content is often considered as a factor that affects the reduction of sulfur $[36,12]$. Based on this, it is necessary to have research on the effect of water hyacinth compost \{Eichhornia crassipes (Martt.) Solm $\}$ and fertilizer $\mathrm{N}, \mathrm{P}, \mathrm{K}, \mathrm{S}$ with balanced doses in increasing the quantity and quality of shallots (Allium ascalonicum L.) on Fluventic Eutrudepts.

\section{Materials and Methods}

This test is carried out in Rumah gauze Field of Soil Chemistry and Plant Nutrition Laboratory Experiments, Faculty of Agriculture, Padjadjaran University, Jatinangor District, Sumedang Regency on February 2020 to August 2020. The tools used are shovels, hoes, polybags $30 \times 30$ cm, scales, callipers, scissors, tape measure, buckets, emrats, tarpaulins, stationery, documentation tools and laboratory equipment. The materials used were planting media in the form of soil with Inceptisol order (Fluventic Eutrudepts subgroup), onion seeds of Batu Ijo variety, compost from water hyacinth, decomposers, Urea fertilizer, SP-36, $\mathrm{KCl}$ and $\mathrm{ZA}$ with various doses according to treatment, and furadan.

This research was conducted using a randomized block design (RAK), which consisted of one control treatment, two recommended dosage treatments of $\mathrm{N}, \mathrm{P}, \mathrm{K}, \mathrm{S}$ fertilizers, and four combination treatments of water hyacinth compost and N, P, K, S fertilizers. Each treatment was repeated four times with two research units totalling 56 polybags. The observations consisted of soil available $\mathrm{S}$ content at 35 DAS (Morgan-Wolf Method), plant S content at 35 DAS (Wet Ashes Method), shallot quantity: wet tuber weight and tuber storage dry weight per plant, and shallot quality: tuber colour testing (Chromameter with Hunter system) and tuber aroma (Organoleptic Test). The experimental data were processed statistically using Fisher's test using the SPSS version 16.0 application. If the effect is significant, the test is continued with the Duncan Multiple Range Test (DMRT) at the 5\% real level.

The first implementation of this research was composting using water hyacinth. First, cut the water hyacinth into small pieces, then add $50 \mathrm{ml}$ of decomposer to each compost pile evenly and stir with a hoe. Composting is done by anaerobically so that the compost is covered with a tarpaulin and is carried out for four weeks. When the temperature on compost pile has dropped to $26^{\circ}-27^{\circ} \mathrm{C}$, the compost is ready to be applied to the field.

The soil is weighed as much as $8 \mathrm{~kg} /$ polybag and then put into a polybag measuring $30 \times 30 \mathrm{~cm}$. Next, mix $25 \mathrm{t} /$ ha of water hyacinth compost with soil and then incubate it for two weeks. Planting carried out by planting one bulb of Batu Ijo Variety on the planting hole. Before planting, the outer skin of the tubers and the remaining roots is cleaned first; then the ends are cut off approximately parts. The fertilizer dosage given is $200 \mathrm{~kg}$ Urea, $500 \mathrm{~kg} Z \mathrm{ZA}, 300 \mathrm{~kg} \mathrm{SP}-36,200 \mathrm{~kg} \mathrm{KCl}$. The application of SP-36 and $\mathrm{KCl}$ fertilizers carried out at planting time. Urea and ZA fertilizers were given at 7 DAS and 21 DAS.

Plant maintenance that is carried out is watering, weeding, pest control, and replanting. Watering is done every day in the morning or evening when it is not raining. Weeding is done manually, which is removing the weeds that grow around the planting medium. Pest control is carried out manually and chemically by administering persisted if it has exceeded the pest attack threshold. Embroidering is done if there are seeds that do not grow or die at the age of 0-14 DAS by pulling out the seeds that do not grow and replacing them with new seeds. Harvesting is done at the age of 60 DAS with the characteristics of soft base stems, $>80 \%$ yellowing and dry leaves, fully filled tubers, and dark red-purple colour. After being harvested, the shallot bulbs are dried for 10 days to obtain the dry 
weight save bulbs.

\section{Results and Discussion}

\subsection{Available-S}

The availability of $\mathrm{S}$ in soil depends on several factors, especially soil redox potential, organic matter content, soil microorganism activity, irrigation quality, and rainwater. The addition of sulfur from both organic and inorganic materials in several agricultural systems can increase organic matter, total organic sulfur, and mineralization of S. Plants obtain available $\mathrm{S}$ apart from soil and fertilizer carrying $\mathrm{S}$ also gets $\mathrm{S}$ from irrigation water, rainwater, and air. In addition to releasing $\mathrm{P}, \mathrm{K}, \mathrm{Ca}, \mathrm{Mg}$, rock weathering also releases $\mathrm{S}$ into the soil solution and releases $\mathrm{SO}_{2}$ and $\mathrm{H}_{2} \mathrm{~S}$ into the free air [7, 26]. The results of statistical tests showed that the application of water hyacinth compost and fertilizers N, P, K, S fertilizers had a significant effect on available-S as presented in Table 1.

Table 1. Effect of Water Hyacinth Compost and N, P, K, S Fertilizer on Available-S Soil.

\begin{tabular}{lll}
\hline Code & Treatment & Available-S (mg/kg) \\
\hline A & Control & $4,03 \mathrm{a}$ \\
B & N, P, K, S recommendations & $21,47 \mathrm{~b}$ \\
C & $3 / 4$ N, P, K, S recommendations & $19,31 \mathrm{~b}$ \\
D & $1 / 2$ compost $+3 / 4$ doses of N, P, K, S & $30,40 \mathrm{de}$ \\
E & Compost $+3 / 4$ doses of N, P, K, S & $32,96 \mathrm{e}$ \\
F & $11 / 2$ compost $+3 / 4$ doses of N, P, K, S & $25,53 \mathrm{c}$ \\
G & Compost + N, P, K, S & $26,63 \mathrm{~cd}$ \\
\hline
\end{tabular}

Note:

Letters of a b c d and e are explain the different significance. The numbers as followed by the same letters in each column are not significantly different according to the Duncan's Multiple Range Test at 5\% level.

Based on the data in Table 1, it can be seen that the application of water hyacinth compost and $\mathrm{N}, \mathrm{P}, \mathrm{K}, \mathrm{S}$ fertilizers can increase the Available-S content in the soil. The provision of water hyacinth compost can provide an environment that supports the availability of sulfate, while the $\mathrm{N}, \mathrm{P}, \mathrm{K}, \mathrm{S}$ fertilizers provided can contribute to the available Available-S into the soil [36]. This can be seen from the increase in Available-S content in the recommended N, P, $\mathrm{K}$, S treatment with Available-S content in the treatment given water hyacinth compost $+\mathrm{N}, \mathrm{P}, \mathrm{K}, \mathrm{S}$ fertilizers which were significantly different. The control treatment had the lowest Available-S content, namely $4.03 \mathrm{mg} / \mathrm{kg}$, the recommended $3 / 4 \mathrm{~N}, \mathrm{P}, \mathrm{K}, \mathrm{S}$ treatment had the lowest S-total content after control, namely $19.31 \mathrm{mg} / \mathrm{kg}$, while the compost treatment $+3 / 4$ dose of N, P, K, S has the highest Available-S at $32.96 \mathrm{mg} / \mathrm{kg}$. This happens because of the $\mathrm{SO}_{4}{ }^{2-}$ content contained in water hyacinth compost and N, P, K, S fertilizers can directly increase the $\mathrm{SO}_{4}{ }^{2-}$ content available in the ground.

Water hyacinth compost that is used as treatment has an $\mathrm{S}$ content of $900 \mathrm{mg} / \mathrm{kg}$, which can increase the $\mathrm{SO}_{4}{ }^{2-}$ content soil through the results of decomposition by microorganisms which will release sulfur as $\mathrm{SO}_{4}{ }^{2-}$. Humic acid from the decomposition of organic matter in the soil can act as an organic ligand so that $\mathrm{SO}_{4}{ }^{2-}$ which is given through sulfur fertilizer, the solubility increases and is available for plants. The addition of water hyacinth compost and N, P, K, S fertilizers can provide a balance of nutrients in the soil so that the amount of Available-S increases because it is not disturbed by the availability of other ions. Humic acid has the ability as a ligand that can bind sulfur to form a complex that can temporarily store nutrients in the soil and release them when plants need it so that the loss of $\mathrm{SO}_{4}{ }^{2-}$ the result of the washing process will be reduced $[36,18]$.

The highest value of Available-S soil was compost treatment $+3 / 4$ dose of $\mathrm{N}, \mathrm{P}, \mathrm{K}, \mathrm{S}$ which was $32.96 \mathrm{mg} / \mathrm{kg}$ but had no significant effect on the treatment of $1 / 2$ compost $+3 / 4$ quantities of N, P, K, S, namely $30.40 \mathrm{mg} / \mathrm{kg}$. Based on this, it shows that using $1 / 2$ amount of water hyacinth compost can increase the total S-content of the soil higher than the recommended $\mathrm{N}, \mathrm{P}, \mathrm{K}, \mathrm{S}$ fertilizer treatment which has a total S-content of $21.47 \mathrm{mg} / \mathrm{kg}$ and can reduce the use of recommended $\mathrm{N}, \mathrm{P}, \mathrm{K}, \mathrm{S}$ fertilizer to be $3 / 4$ dose.

The treatment without water hyacinth compost or N, P, K, $\mathrm{S}$ fertilizers had the lowest total $\mathrm{S}$ content of $4.03 \mathrm{mg} / \mathrm{kg}$. This happened because the availability of $S$ in the soil was influenced by organic matter. Aerobic soil conditions or not inundated and acidic can encourage the formation of $\mathrm{SO}_{4}{ }^{2-}$ ionsfaster through the mineralization process of organic sulfur compounds which will release $\mathrm{H}_{2} \mathrm{~S}$ and be oxidized to $\mathrm{SO}_{4}{ }^{2-}$ by chemotrophic sulfur bacteria (Beggiatoa thiothrix) or microorganisms from the genus Thiobacillus [19, 29]. This possibility causes the $\mathrm{SO}_{4}{ }^{2-}$ content $\mathrm{In}$ the treatment of water hyacinth compost, S-availability was higher than the treatment without water hyacinth compost.

\subsection{S Uptake}

Elemental $\mathrm{S}$ is absorbed by plants in the form of $\mathrm{SO}_{4}{ }^{2-}$ and $\mathrm{HSO}_{4}{ }^{-}$ions. The nutrient $\mathrm{S}$ will poison the shallot plant if it is interested in too large a quantity. However, on the other hand, the need for $\mathrm{S}$ nutrients is quite a lot. The $\mathrm{SO}_{4}{ }^{2-}$ and $\mathrm{HSO}_{4}{ }^{-}$ions that are absorbed by plants in physiological processes will be captured and reduced by ATP to form APS (Adenosine Posfo Sulfate) which is not poisonous to plants. S uptake plays almost the same role as in $\mathrm{N}$, especially in the synthesis of amino acids and proteins. The $\mathrm{S}$ element together with the $\mathrm{C}, \mathrm{H}, \mathrm{O}, \mathrm{N}, \mathrm{P}$, and $\mathrm{K}$ elements are the building blocks of protein $[40,36]$. The results of statistical tests showed that the application of water hyacinth compost and $\mathrm{N}, \mathrm{P}, \mathrm{K}, \mathrm{S}$ fertilizers had a significant effect on plant $\mathrm{S}$ uptake as presented in Table 2.

Table 2. Effect of Water Hyacinth Compost and N, P, K, S Fertilizer on Plant $S$ Uptake.

\begin{tabular}{lll}
\hline Code & Treatment & S Uptake (mg/plant) \\
\hline A & Control & $1,16 \mathrm{a}$ \\
B & N, P, K, S recommendations & $3,01 \mathrm{~b}$ \\
C & $3 / 4$ N, P, K, S recommendations & $3,53 \mathrm{bc}$ \\
D & $1 / 2$ compost $+3 / 4$ doses of N, P, K, S & $3,80 \mathrm{~cd}$ \\
E & Compost $+3 / 4$ doses of N, P, K, S & $4,29 \mathrm{~d}$ \\
F & $11 \frac{1}{2}$ compost $+3 / 4$ doses of N, P, K, S & $3,18 \mathrm{bc}$ \\
\hline
\end{tabular}




\begin{tabular}{lll}
\hline Code & Treatment & S Uptake (mg/plant) \\
\hline G & Compost + N, P, K, S & $3,80 \mathrm{~cd}$ \\
\hline
\end{tabular}

Note:

Letters of $a b c$ and $d$ are explain the different significance. The numbers as followed by the same letters in each column are not significantly different according to the Duncan's Multiple Range Test at 5\% level.

Based on the data in Table 2, it can be seen that water hyacinth compost and N, P, K, S fertilizers can significantly increase the absorption of sulfur by plants. In the treatment without water hyacinth compost and N, P, K, S fertilizers had the lowest $\mathrm{S}$ absorption value among other remedies, namely $1.16 \mathrm{mg} / \mathrm{plant}$, while the compost treatment $+3 / 4$ doses of $\mathrm{N}, \mathrm{P}$, $\mathrm{K}, \mathrm{S}$ had absorption values. The highest $\mathrm{S}$ was $4.29 \mathrm{mg} / \mathrm{plant}$. Increased absorption of sulfur by plants is related to the availability of sulfur in the soil [16]. This is evident from the availability of $S$ resulting from the compost treatment $+3 / 4$ doses of N, P, K, S has the highest Available-S among other treatments.

Treatment of $1 / 2$ compost $+3 / 4$ dose of $\mathrm{N}, \mathrm{P}, \mathrm{K}, \mathrm{S}$ and compost $+3 / 4$ dose of $\mathrm{N}, \mathrm{P}, \mathrm{K}, \mathrm{S}$ gave $\mathrm{S}$ uptake results that were not significantly different, or the increase was not too high with compost treatment $+3 / 4$ doses of $\mathrm{N}, \mathrm{P}, \mathrm{K}, \mathrm{S}$ which has an $\mathrm{S}$ absorption value of $3.80 \mathrm{mg} /$ plant. This not too high increase in sulfur absorption shows that the plant's need for sulfur is basically fulfilled and optimum with the treatment of $1 / 2$ compost $+3 / 4$ doses of $N, P, K, S$. Apart from giving water hyacinth compost and fertilizers N, P, K, Sulfur supply can be sourced from rainwater, irrigation water, and is directly absorbed by the leaves in $\mathrm{SO}_{2}$ from the air so that the need for sulfur for plants is very fulfilled, although some are lost through washing [36]. The availability of soil Sulfur for plants can be affected by various conditions in the soil.

The recommended $\mathrm{N}, \mathrm{P}, \mathrm{K}, \mathrm{S}$ treatments have the lowest $\mathrm{S}$ uptake value after control compared to other treatments, namely $3.01 \mathrm{mg} /$ plant. This can occur because of the short dry weight value of stover and the low Available-S soil content, besides that $\mathrm{S}$ in the soil is also easily leached out because $\mathrm{S}$ is mobile in the ground so that the $\mathrm{S}$ absorption value is too low. Based on this, adding water hyacinth compost will give better results than without water hyacinth compost. The addition of water hyacinth compost can provide a balance of nutrients in the soil so that the amount of Available-S increases. Humic acid results from the decomposition of organic matter in the soil increase the ability of the ground to bind, absorb, and can provide nutrients such as $\mathrm{N}, \mathrm{P}, \mathrm{K}$ and $\mathrm{S}$ into the soil and $\mathrm{C}$ as a source of energy for soil microbes $[42,18]$.

\subsection{Fresh Bulbs Weight}

The application of organic fertilizers to cultivated plants has been shown to have a positive impact on soil fertility, soil physical properties, and yields [13]. The results of statistical tests showed that the application of water hyacinth compost and N, P, K, S fertilizers had a significant effect on the fresh weight of shallots as presented in Table 3 .
Table 3. Effect of Water Hyacinth Compost and N, P, K, S Fertilizer on Fresh Bulbs Weight.

\begin{tabular}{lll}
\hline Code & Treatment & $\begin{array}{l}\text { Fresh Bulbs Weight } \\
\text { (g/clump) }\end{array}$ \\
\hline A & Control & $74,10 \mathrm{a}$ \\
B & N, P, K, S recommendations & $95,19 \mathrm{~b}$ \\
C & $3 / 4 \mathrm{~N}, \mathrm{P}, \mathrm{K}, \mathrm{S}$ recommendations & $96,28 \mathrm{~b}$ \\
$\mathrm{D}$ & $1 / 2$ compost $+3 / 4$ doses of N, P, K, S & $113,24 \mathrm{c}$ \\
E & Compost $+3 / 4$ doses of N, P, K, S & $117,41 \mathrm{c}$ \\
$\mathrm{F}$ & $11 / 2$ compost $+3 / 4$ doses of N, P, K, S & $102,60 \mathrm{bc}$ \\
G & Compost $+\mathrm{N}, \mathrm{P}, \mathrm{K}, \mathrm{S}$ & $108,33 \mathrm{bc}$ \\
\hline
\end{tabular}

Note:

Letters of $a b$ and $c$ are explain the different significance. The numbers as followed by the same letters in each column are not significantly different according to the Duncan's Multiple Range Test at 5\% level.

Based on the data in Table 3, it can be seen that the treatment of water hyacinth compost + fertilizer N, P, K, S on average fresh weight of tubers shows significantly different results compared to treatment using only fertilizer $\mathrm{N}, \mathrm{P}, \mathrm{K}, \mathrm{S}$. the average new value of tubers of $117.41 \mathrm{~g}$ is the compost treatment $+3 / 4$ doses of $\mathrm{N}, \mathrm{P}, \mathrm{K}, \mathrm{S}$, while the lowest result is in the control treatment with an average tuber fresh weight of $74.10 \mathrm{~g}$. This happened because there was no addition of water hyacinth compost or N, P, K, S fertilizers so that plant nutrient needs could not be met. According to Mehran et al. [22] stated that the application of $\mathrm{N}, \mathrm{P}, \mathrm{K}, \mathrm{S}$ fertilizers could significantly affect the fresh weight of shallot plant tubers.

The higher the dose of sulfur fertilizer that is given does not necessarily result in a higher fresh weight. It can be seen that the treatment of compost $+\mathrm{N}, \mathrm{P}, \mathrm{K}, \mathrm{S}$ gives an average yield of lower tuber new value compared to the treatment of $1 / 2$ compost $+3 / 4$ doses of $N, P, K, S$, which are respectively equal to $108.33 \mathrm{~g}$ and $113.24 \mathrm{~g}$. This happens because of the treatment $1 / 2$ compost $+3 / 4$ dose of $N, P, K, S$ indicates that the nutrient requirements for plants are fulfilled. In line with Soenyoto's research [35] which states that fertilizers given with optimal doses increase plant height and the number of tillers which will affect the fresh weight of shallot bulbs.

The higher the dose of sulfur fertilizer that is given does not necessarily result in a higher fresh weight. It can be seen that the treatment of compost $+\mathrm{N}, \mathrm{P}, \mathrm{K}, \mathrm{S}$ gives an average yield of lower tuber new value compared to the treatment of $1 / 2$ compost $+3 / 4$ doses of $\mathrm{N}, \mathrm{P}, \mathrm{K}, \mathrm{S}$, which are respectively equal to $108.33 \mathrm{~g}$ and $113.24 \mathrm{~g}$. This happens because of the treatment $1 / 2$ compost $+3 / 4$ dose of $\mathrm{N}, \mathrm{P}, \mathrm{K}, \mathrm{S}$ indicates that the nutrient requirements for plants are fulfilled. In line with Soenyoto's research (2016) which states that fertilizers given with optimal doses increase plant height and the number of tillers which will affect the fresh weight of shallot bulbs.

Treatment of $1 / 2$ compost + doses of $N, P, K, S$ gave results that the fresh weight of the tubers was not significantly different from the compost treatment $+3 / 4$ amounts of $\mathrm{N}, \mathrm{P}, \mathrm{K}$, $\mathrm{S}$, which was $113.24 \mathrm{~g}$. This happens because water hyacinth bokashi is a superior organic material with the excess element of sulfur it has. Onion plants with fertilizers containing sulfur can increase the growth of leaf area, a 
number of tubers, plant fresh weight per clump, plant dry weight per clump and tuber weight per hill in shallot plants $[36,28]$.

\subsection{Dry Weight Save Bulbs}

Sulfur is an essential nutrient needed by plants. Sulfur is necessary for the growth and development of onion plants $[44,5]$. The results of statistical tests showed that the application of water hyacinth compost and N, P, K, S fertilizers had a significant effect on the dry weight of shallot storage as presented in Table 4.

Table 4. Effect of Water Hyacinth Compost and N, P, K, S Fertilizer on Dry Weight Save Bulbs.

\begin{tabular}{lll}
\hline Code & Treatment & $\begin{array}{l}\text { Dry Weight Save } \\
\text { Bulbs (g/clump) }\end{array}$ \\
\hline A & Control & $45,53 \mathrm{a}$ \\
B & N, P, K, S recommendations & $63,30 \mathrm{~b}$ \\
C & $3 / 4 \mathrm{~N}, \mathrm{P}, \mathrm{K}, \mathrm{S}$ recommendations & $62,10 \mathrm{~b}$ \\
$\mathrm{D}$ & $1 / 2$ compost $+3 / 4$ doses of N, P, K, S & $83,83 \mathrm{c}$ \\
$\mathrm{E}$ & Compost $+3 / 4$ doses of N, P, K, S & $89,38 \mathrm{c}$ \\
$\mathrm{F}$ & $11 / 2$ compost $+3 / 4$ doses of N, P, K, S & $78,57 \mathrm{c}$ \\
G & Compost $+\mathrm{N}, \mathrm{P}, \mathrm{K}, \mathrm{S}$ & $80,68 \mathrm{c}$ \\
\hline
\end{tabular}

Note:

Letters of $a b$ and $c$ are explain the different significance. The numbers as followed by the same letters in each column are not significantly different according to the Duncan's Multiple Range Test at 5\% level.

Based on the data in table 4, it can be seen that the application of water hyacinth compost has a significant effect on the dry storage weight of the tubers when compared to only providing fertilizer $\mathrm{N}, \mathrm{P}, \mathrm{K}, \mathrm{S}$. Compost treatment $+3 / 4$ doses of N, P, K, S give dry weight results. The highest store among other treatments was $89.38 \mathrm{~g}$. However, the treatment of water hyacinth compost dosage on the dry storage weight of the tubers was not significantly different. Treatment of $3 / 4$ $\mathrm{N}, \mathrm{P}, \mathrm{K}, \mathrm{S}$ recommendation and treatment of $\mathrm{N}, \mathrm{P}, \mathrm{K}, \mathrm{S}$ recommendation gave a lower yield of dry tuber weight compared to treatment with the addition of water hyacinth compost. This happens because organic matter can increase the ability of the soil to hold water so that nutrients in the ground are not easily lost because they are washed [14]. According to Anisyah et al. [3], the application of organic matter affects the dry weight of tubers per sample in shallot plants. In line with the research results of Lasmini, et al. [21], show that the use of organic fertilizers and inorganic fertilizers can increase yield, quality of shallot tubers, soil quality, and efficiency of inorganic fertilizers.

The treatment of $1 \frac{1}{2}$ compost $+3 / 4$ doses of $N, P, K, S$ gave lower yields of dry weight than the therapy of $1 / 2$ compost + quantities of N, P, K, S, namely $78.57 \mathrm{~g}$ and $83.83 \mathrm{~g}$. This can happen because of fertilizer given is ineffective so that the nutrients in the soil are excessive and result in disturbed nutrient balance. According to Nurjaya and Wibowo [23], disruption of nutrient balance in the soil results in disturbed metabolic processes so that plant yields can decrease. The advantage of water hyacinth compost is that it has a high sulfur content. Sulfur in the soil will affect the $\mathrm{pH}$ value of the ground $[17,37]$. If fertilizers containing sulfur are given excessively, it will acidify the soil and harm the plants because it will bind other nutrients so that it will be difficult for plants to absorb.

The lowest yield of dry storage weight of shallot bulbs was in the treatment without water hyacinth compost and N, P, K, $\mathrm{S}$ fertilizers, namely an average of $45.53 \mathrm{~g}$. This happens because of the low availability of nutrients in the soil so that the results obtained are also low.

\subsection{Bulbs Colour}

The results of statistical tests showed that the application of water hyacinth compost and N, P, K, S fertilizers had a significant effect on the colour of shallot bulbs as presented in Table 5.

Table 5. Effects of Water Hyacinth Compost and N, P, K, S Fertilizer on Bulbs Color.

\begin{tabular}{|c|c|c|c|c|}
\hline \multirow{2}{*}{ Code } & \multirow{2}{*}{ Treatment } & \multicolumn{3}{|c|}{ Bulbs Colour } \\
\hline & & $\mathbf{L}^{*}$ & $a^{*}$ & $\mathbf{b}^{*}$ \\
\hline $\mathrm{A}$ & Control & $35,56 \mathrm{a}$ & $14,75 \mathrm{a}$ & $-1,68 \mathrm{a}$ \\
\hline B & $\mathrm{N}, \mathrm{P}, \mathrm{K}, \mathrm{S}$ recommendations & 42,16 a & $21,39 \mathrm{bc}$ & $-3,17$ a \\
\hline $\mathrm{C}$ & $3 / 4 \mathrm{~N}, \mathrm{P}, \mathrm{K}, \mathrm{S}$ recommendations & $42,36 \mathrm{a}$ & $20,20 \mathrm{~b}$ & $-4,20 \mathrm{a}$ \\
\hline $\mathrm{D}$ & $1 / 2$ compost $+3 / 4$ doses of $N, P, K, S$ & $43,44 \mathrm{a}$ & $23,23 \mathrm{bc}$ & $-3,76 a$ \\
\hline $\mathrm{E}$ & Compost $+3 / 4$ doses of N, P, K, S & $43,10 \mathrm{a}$ & $22,92 \mathrm{bc}$ & $-3,75$ a \\
\hline $\mathrm{F}$ & $1 \frac{1}{2}$ compost $+3 / 4$ doses of $N, P, K, S$ & $42,88 \mathrm{a}$ & $22,14 \mathrm{bc}$ & $-3,59 a$ \\
\hline $\mathrm{G}$ & Compost + N, P, K, S & $42,31 \mathrm{a}$ & $24,03 \mathrm{c}$ & $-2,42 \mathrm{a}$ \\
\hline
\end{tabular}

Note:

Letters of $\mathrm{a} b$ and $\mathrm{c}$ are explain the different significance. The numbers as followed by the same letters in each column are not significantly different according to the Duncan's Multiple Range Test at 5\% level.

Colour is an essential factor in assessing the quality of shallots. Colour measurements are carried out using the Hunter system with a chromameter designed to resemble human vision using three components, namely L (Lightness) or ranged colour brightness, green-red dimensions represented by the letter a, and blue-yellow dimensions represented by letters $b$ [39].
The $\mathrm{L}^{*}$ and $\mathrm{b}^{*}$ values in each treatment based on the results of statistical tests had no significant effect. Based on the data in Table 5, it can be seen that the colour of the red tubers is dominated by red which is indicated by the greater the value of $a^{*}$ compared to the amount of $b^{*}$. The compost treatment $+\mathrm{N}, \mathrm{P}, \mathrm{K}, \mathrm{S}$ had the highest $\mathrm{a}^{*}$ value among the other treatments, which was 24.03, while the control 
treatment had the lowest $a^{*}$ cost, which was 14.75 . This happens because, in the control treatment, there is no addition of potassium fertilizer because the element potassium influences the colour of the tubers. The colour of the tuber is closely related to the water content it has. The water content in shallots is greatly influenced by the availability of potassium [14]. In line with research results Sembiring [32], the application of $\mathrm{K}$ fertilizer doses significantly affected crop production and yield, namely tuber weight and bulb colour on shallot plants.

The red colour produced in onion bulbs is thought to be due to the presence of anthocyanin compounds. Anthocyanins are natural pigments that are widely distributed in nature. Anthocyanin compounds are a subclass of flavonoids and give many flowers, fruits and vegetables their red, purple, and blue colours. The colour stability of anthocyanins is influenced by $\mathrm{pH}$, type of solvent, temperature, oxygen, light, and enzymes [10, 25].

Loss of colour in shallot bulbs can be caused by the oxidation of carotene and xanthophyll pigments which occurs gradually due to contact with free air [2]. Based on research results Sembiring (2018), in acidic soil conditions, anthocyanins will form well. A stable anthocyanin will give a bright colour at an acidic $\mathrm{pH}$, and vice versa will slowly lose colour as $\mathrm{pH}$ increases and become colourless (pale).

\subsection{Bulbs Aroma}

The results of statistical tests showed that the application of water hyacinth compost and N, P, K, S fertilizers had a significant effect on the aroma of shallot bulbs as presented in Table 6.

Table 6. Effects of Water Hyacinth Compost and N, P, K, S Fertilizer on Aroma Bulbs.

\begin{tabular}{lll}
\hline Code & Treatment & Bulbs Aroma \\
\hline A & Control & $4,2 \mathrm{a}$ \\
B & N, P, K, S recommendations & $5,9 \mathrm{bc}$ \\
C & $3 / 4$ N, P, K, S recommendations & $5,3 \mathrm{~b}$ \\
D & $1 / 2$ compost $+3 / 4$ doses of N, P, K, S & $6,2 \mathrm{~cd}$ \\
E & Compost $+3 / 4$ doses of N, P, K, S & $6,6 \mathrm{~d}$ \\
F & $1 \frac{1}{2}$ compost $+3 / 4$ doses of N, P, K, S & $6,2 \mathrm{~cd}$ \\
G & Compost + N, P, K, S & $6,0 \mathrm{~cd}$ \\
\hline
\end{tabular}

Note:

Letters of $\mathrm{a} \mathrm{b} \mathrm{c}$ and $\mathrm{d}$ are explain the different significance. The numbers as followed by the same letters in each column are not significantly different according to the Duncan's Multiple Range Test at 5\% level.

The tuber aroma was tested by Organoleptic Test. The organoleptic test is to measure the sensing process, namely sight with the eyes, smell with the nose, taste with the oral cavity, touch with the fingertips, and hearing with the ear. In the liking test for smells, sensitivity greatly influenced the assessment. One of the physiological factors that affect sensitivity is the conditions of fullness and hunger. Too full reduces sensitivity, and too hungry can lead to over-judgment [34].

Based on the data in Table 6 , it can be seen that the compost treatment $+3 / 4$ doses of $N, P, K, S$ give the highest average tuber aroma value, which is 6.6 which is classified as a stinging criterion. This treatment also had the highest Available-S weight and S uptake, among other treatments. This shows that the higher the sulfur absorbed by the plant, the more pungent the tuber aroma will be. The distinctive scent is closely related to the sulfur content. Giving water hyacinth compost and ZA fertilizer to shallot plants containing $\mathrm{N}$ and $\mathrm{S}$, which affect tuber formation and tuber aroma [14].

The primary function of $\mathrm{S}$ for onion plants includes forming amino acids that contain $\mathrm{S}$ elements such as cystine, cysteine and methionine. These amino acids affect the distinctive aroma of shallots, the higher the content, the better the quality of the onions produced. The smell is obtained from sulfoxide compounds $[4,16]$.

The lowest average tuber aroma value was the control treatment of 4.2 , which is classified as a mildly stinging criterion. This occurs because the availability of nutrients in the soil in the control treatment is low so that it affects the quality of the tubers produced. The availability of sulfate in the soil is often a limiting factor for shallot plants to produce tubers of good weight and quality. According to Schnug [31], sulfur plays a vital role in plant metabolism, which is related to several parameters that determine the nutritional quality of vegetable crops. The acuity of onion aroma correlates with the availability of $\mathrm{S}$ in the soil [15].

\section{Conclusions}

1. Treatment water hyacinth compost \{Eichhornia crassipes (Martt.) Solm \}and fertilizers N, P, K, S affect changes in sulfur, quantity and quality of shallots (Allium Ascalonicum L.) on Fluventic Eutrudepts.

2. A dose of $25 \mathrm{t} / \mathrm{ha}$ of water hyacinth compost +150 $\mathrm{kg} / \mathrm{ha}$ Urea, $225 \mathrm{~kg} / \mathrm{ha} \mathrm{SP-36,} 150 \mathrm{~kg} / \mathrm{ha} \mathrm{KCl,} 375 \mathrm{~kg} / \mathrm{ha}$ $\mathrm{ZA}$ is able to provide the best effect in increasing the quantity and quality of shallots (Allium ascalonicum L.) on Fluventic Eutrudepts.

3. Dry weight save bulbs per hectare with the treatment dose of $25 \mathrm{t} / \mathrm{ha}$ of water hyacinth compost $+150 \mathrm{~kg} / \mathrm{ha}$ Urea, $225 \mathrm{~kg} / \mathrm{ha} \mathrm{SP-36,} 150 \mathrm{~kg} / \mathrm{ha} \mathrm{KCl}, 375 \mathrm{~kg} / \mathrm{ha} \mathrm{ZA}$ gave $41 \%$ advantage compared to the recommendation $\mathrm{N}, \mathrm{P}, \mathrm{K}, \mathrm{S}$ treatment.

\section{Acknowledgements}

The research funding was provided by Soil Chemistry and Plant Nutrition Laboratory, Faculty of Agriculture, Universitas Padjajaran.

\section{References}

[1] Afrilliana, N. 2017. Pengaruh Penambahan Pupuk $\mathrm{KCl}$ terhadap Pertumbuhan Dan Produksi Bawang Merah (Allium ascalonicum L.) Berbasis Pupuk Organik Berbeda: Skripsi. Program Studi Agroteknologi. Fakultas Peternakan dan Pertanian. Universitas Diponegoro. Semarang. 
[2] Amiarsi, D., Sasmitaloka, K. S., Arif, A. B., and Widayanti, S. M. 2019. Curing Process Modification of Shallot Through Cutting Leaves. In IOP Conference Series: Earth and Environmental Science (Vol. 309, No. 1, p. 012022). IOP Publishing.

[3] Anisyah, F., R. Sipayung, dan C. Hanum. 2014. Pertumbuhan dan Produksi Bawang Merah dengan Pemberian Berbagai Pupuk Organik. Jurnal Online Agroekoteknologi 2 (2): 482 496.

[4] Anjar S. L., Imam, W., B. Nasir, dan Rosmini. 2017. Pertumbuhan dan hasil Bawang Merah Lembah Palu pada Berbagai Dosis Pupuk Organik Cair Biokultur Urin Sapi. J. Agroland Vol. 24 (3): 199-207.

[5] Assefa, A. G., S. H. Mesgina, and Y. W. Abrha. 2015. Response of Onion (Allium Cepa L.) Growth and Yield to Different Combinations of N, P, S, Zn Fertilizers and Compost in Northern Ethiopia. International Journal of Science and Research (IJSR) 4 (2): 985-989.

[6] Badan Pusat Statistik. 2018. Statistik Indonesia Tahun. Jakarta Pusat: Badan Pusat Statistik.

[7] Danapriatna, N. 2008. Peranan sulfur bagi pertumbuhan tanaman. Paradigma, 9 (1), 39-52.

[8] Dirgantari, S., Halimursyadah dan Syamsuddin. 2016. Respon Pertumbuhan dan Hasil Bawang Merah (Allium ascalonicum) terhadap Kombinasi Dosis NPK dan Pupuk Kandang. J. Ilmiah Mahasiswa Pertanian Unsyiah Vol. 1 (1).

[9] Efendi, E., W. Deddy Purba dan Nida U. H. Nasution. 2017. Respon Pemberian Pupuk NPK Mutiara dan Bokashi Jerami Padi terhadap Pertumbuhan dan Produksi Tanaman Bawang Merah (Allium ascalonicum L.). J. Penelitian BERNAS Vol. $13(3)$.

[10] Einbond L. S., Reynerston K. A., Luo X. D., Basile M. J., and Kennelly E. J., 2004. Anthocyanin antioxidants from edible fruits. Elsevier Food Chemistry 84: 23-28.

[11] Elisabeth, D. W., Santoso, M., dan Herlina, N. 2013. Pengaruh pemberian berbagai komposisi bahan organik pada pertumbuhan dan hasil tanaman bawang merah (Allium ascalonicum L.). Jurnal Produksi Tanaman, 1 (3).

[12] Goenadi. 2000. Teknik Pembuatan Kompos. Rajawali, Jakarta

[13] Govere. S., B. Madziwa, and P. Mahlatini. 2011. The Nutrient of Organic Liquid Fertilizer in Zimbabwe. International Journal of Modern Engineering Research (IJMER) 1 (1): 196202.

[14] Halifah, U. N., Roedy S. dan Mudji S. 2015. Pengaruh Pemberian Pupuk Organik (Blotong) dan Pupuk Anorganik (ZA) terhadap Tanaman Bawang Merah (Allium ascalonicum L.). J. Produksi Tanaman Vol. 2 (8): 665-672.

[15] Hamilton, B. K., Kul Sun Yoo, and L. M. Pike. 1998. Changes in pungency of onions by soil type, sulphur nutrition and bulb maturity. Sci. Horti. 74: 249-256.

[16] Hardjowigeno, S. 2010. Ilmu Tanah. Akademika Pressindo. Jakarta.

[17] Hazmi, M., dan R. Hartoyo. 2014. Respons Pertumbuhan dan Produksi Kacang Tanah terhadap Aplikasi Pupuk SP-36 dan Pupuk Cair Hayati. Agritrop. Jurnal Ilmu-Ilmu Pertanian Vol. 12 No. 2: $102-106$.
[18] Hermanto, D. N. K. T., Dharmayani, N. K., Kurnianingsih, R., dan Kamali, S. R. 2013. Pengaruh asam humat sebagai pelengkap pupuk terhadap ketersediaan dan pengambilan nutrien pada tanaman jagung di lahan kering Kecamatan Bayan-NTB. Ilmu Pertanian (Agricultural Science), 16 (2), 28-41.

[19] Hidayati, N. 2011. Kajian pengaruh berbagai formula biosulfo terhadap ketersediaan fosfor dan belerang serta hasil kedelai (Glycine max L.) pada tanah vertisol.

[20] Kementrian Perdagangan. 2016. Profil Komoditas Barang Kebutuhan Pokok dan Barang Penting: Komoditas Bawang Merah.

[21] Lasmini, S. A., Z. Kusuma, M. Santosa, A. L. Abadi. 2015. Application of organic and inorganic fertilizer improving the quantity and quality of shallot yield on dry land. Int. J. Sci. Tech. Res. 4 (4): 243-246.

[22] Mehran., E. Kesumawati, dan Sufardi. 2016. Pertumbuhan dan Hasil Beberapa Varietas Bawang Merah (Allium Ascalonicum L.) pada Tanah Aluvial akibat Pemberian Berbagai Dosis Pupuk NPK. Jurnal Floratek Vol. 11 No. 2: 117-133.

[23] Nurjaya dan H. Wibowo. 2018. Kebutuhan Pupuk MOP pada Tanah Inceptisols Bogor dengan Status Hara K-Potensial dan K-Tersedia Rendah untuk Tanaman Jagung. Prosiding Peluang dan Tantangan Pembangunan Pertanian Berkelanjutan di Era Global dan Digital.

[24] Ratnawati. 2017. Pengendalian Hama dan Penyakit pada Tanaman Bawang Merah. Litbang Pertanian Hal. 298.

[25] Rein, M. J. 2005. Copigmentation Reactions and Color Stability of Berry Anthocyanins. Dissertation. EKT series 1331. University of Helsinki, Department of Applied Chemistry and Microbiology.

[26] Rosmarkam dan Nasih Widya Yuwono. 2002. Ilmu Kesuburan Tanah. Kanisius. Yogyakarta.

[27] Sahwan, F. L. 2016. Kualitas Produk Kompos dan Karakteristik Proses Pengomposan Sampah Kota Tanpa Pemilahan Awal. Jurnal Teknologi Lingkungan, 11 (1), 79-85.

[28] Sakhidin, S., Kharisun, K., dan Juwanda, M. 2020. Inovasi Teknologi Pupuk Hayati dan Kompos Daun Bawang Merah untuk Meningkatkan Hasil Bawang Merah. Prosiding, 9 (1).

[29] Sari, M. N., Sudarsono, dan Darmawan. 2017. Pengaruh bahan organik terhadap ketersediaan fosfor pada tanah-tanah kaya Al dan Fe. Buletin Tanah dari Lahan 1 (1): 65-71.

[30] Sartono, P. 2010. Perbaikan Varietas Bawang Merah (Allium ascallonicum L.) Melalui Persilangan Agritech., Vol. XII. Hal. $1-10$.

[31] Schnug, E. 1990. Sulphur nutrition and quality ofvegetable. Sulphur in Agr. 14: 3-6.

[32] Sembiring, M. 2018. Perubahan Pertumbuhan dan Produksi Bawang Merah (Allium ascalonicum L.) dari Pengaruh Penggunaan Pupuk Organik dan Dosis Pupuk KC1. Jurnal Agroteknosains, 1 (2).

[33] Setyastika, U. S., dan Suntari, R. 2019. Pengaruh Aplikasi Bokashi terhadap Dinamika Ketersediaan N, P, dan S pada Inceptisol Karangploso, Malang. Jurnal Tanah dan Sumberdaya Lahan, 6 (2), 1291-1299. 
[34] Soekarto, S. T. 1985. Dasar-Dasar Pengawasan dan Standarisasi Mutu Pangan. Jurusan Teknologi Pangan dan Gizi. Departemen Pendidikan dan Kebudayaan. Direktorat Jenderal Pendidikan Tinggi. Pusat Antar Universitas Pangan dan Gizi Institut Pertanian Bogor, Bogor.

[35] Soenyoto, E. 2016. Pengaruh Dosis Pupuk Anorganik NPK Mutiara (16:16:16) dan Pupuk Organik Mashitam Terhadap Pertumbuhan dan Produksi Tanaman Bawang Merah (Allium ascalonicum L.) Varietas Bangkok Thailand. Jurnal Hijau Cendekia Vol 1. No. 1: 21-27.

[36] Sofyan, Emma. 2014. Pengaruh Pupuk Kascing dan SP-36 Terhadap Beberapa Sifat Kimia Tanah dan Hasil Tanaman Buncis Pada Fluventic Eutrudepts Jatinangor Kabupaten Sumedang.

[37] Souza, A. B. C. Filho, F. A. Tulio, and R. H. D Nowaki. 2015. Effect of Sulphur dose on the productivity and quality of onions. Australian Journal of Crop Science 9 (8): 728-733

[38] Sudirja, Rija, Benny Joy, Anni Yuniarti, Emma Trinuriani, Oviyanti Mulyani dan Arini Mushfiroh. 2017. Beberapa Sifat Kimia Tanah Inceptisol dan Hasil Kedelai (Glycine max L.) Akibat Pemberian Bahan Amelioran. Prosiding Seminar Hasil Penelitian Tanaman Aneka Kacang dan Umbi.
[39] Suyatma. 2009. Diagram Warna Hunter (Kajian Pustaka). Jurnal Penelitian Ilmiah Teknologi Pertanian. IPB. Bogor.

[40] Tjionger, M. 2010. Memperbesar dan Merperbanyak Umbi Bawang Merah. Indonesia Agriculture. http: obtrando. wordpress.com (22 April 2010). Trudinger, P. A. 1996. Chemistry of The Sulphur Cycle. P. 2-22. In: M. A.

[41] Wati, Y. T., Nurlaelih, E. E., dan Santoso, M. 2015. Pengaruh aplikasi biourin pada pertumbuhan dan hasil tanaman bawang merah (Allium ascalonicum L.). Jurnal Produksi Tanaman, 2 (8).

[42] Winarso, S., 2005. Kesuburan Tanah Dasar Kesehatan dan Kualitas Tanah. Gava Media. Yogyakarta.

[43] Wulandari, D. A., Linda, R., dan Turnip, M. 2016. Kualitas Kompos dari Kombinasi Eceng Gondok (Eichornia crassipes Mart. Solm) dan Pupuk Kandang Sapi dengan Inokulan Trichoderma harzianum L. Protobiont, 5 (2).

[44] Zhao, C., F. Degryse, F. Gupta, and M. J. McLaughlin. 2015. Elemental Sulfur Oxidation in Australian Cropping Soils. Soil Science Society of America Journal 79: 89-9. 